\title{
The Status of Pragmatics among Iranian EFL Learners
}

\author{
Mehri Mohammad-Bagheri ${ }^{1}$ \\ ${ }^{1}$ Department of Persian Literature and Foreign Languages, University of Allameh Tabatabai, Tehran, Iran \\ Correspondence: Mehri Mohammad-Bagheri, Department of Persian Literature and Foreign Languages, \\ University of Allameh Tabatabai, Tehran, Iran. E-mail: mmbaqeri@gmail.com
}

Received: January 4, 2015 Accepted: February 6, 2015 Online Published: March 25, 2015

doi:10.5539/elt.v8n4p67 URL: http://dx.doi.org/10.5539/elt.v8n4p67

\begin{abstract}
The present study attempted to investigate the status of pragmatics among Iranian EFL learners. Status of pragmatics was analyzed in terms of the amount of pragmatic knowledge EFL leaners believed to have and the amount of pragmatic knowledge they believed to receive from teachers, classmates, course books, and exams. Additionally, attempts were made to find out whether or not there is a significant difference between male and female EFL learners in terms of pragmatic awareness.

Results showed that Iranian EFL learners were aware of the importance of pragmatics and attributed a high level of pragmatic awareness to their teachers, but believed that they did not receive enough pragmatic knowledge from their teachers. The frequent method used by their teachers to teach pragmatics was error correction. Besides, learners believed that their classmates did not care enough about pragmatics, and course book and exams, from their point of view, did not cover enough pragmatic information. Gender played a significant role in pragmatic awareness of Iranian EFL learners.
\end{abstract}

Keywords: pragmatics, pragmatic awareness, EFL, gender

\section{Introduction}

The concept of pragmatic competence entered the realm of language teaching after the advent of communicative competence models proposed by a number of scholars (Bachman, 1990; Bachman \& Palmer, 1996; Canale, 1983; Canale \& Swain, 1980). Before that, the field of language teaching was mostly obsessed by formal aspects of language such as grammar, vocabulary, and pronunciation, with little emphasis on methods which enable language learners to communicate appropriately in real language use context. In Canale and Swain's (1980) model, pragmatic competence was highlighted as a subset of sociolinguistic competence. Later, Bachman (1990) made the role of pragmatic competence more prominent by defining it as one of the two components of language competence along with organizational competence.

Many studies so far have been conducted with the purpose of identifying the best methods of boosting language learners' pragmatic competence. Nevertheles, despite its important role for appropriate communication, pragmatics has not yet received a deserving role in curriculum of English language learners, especially in EFL context. This ignored role is apparent from the numerous number of language learner who struggle with communicative aspects of language even after years of language learning. The present study is an attempt to investigate pragmatic awareness of Iranian EFL learners from different dimensions. In other words, it is attempted to shed light on the quality of different factors which contribute to pragmatic competence of language learners such as teachers, course materials, tests, institutes'authorities, etc. Beside that, the role of gender on pragmatic awareness of Iranian EFL learners is analysed. Looking at different factors which contribute to learners' pragmatic competence would enable EFL/ESL researchers to find out deficiencies which exist in this field and consequently help with finding better methods of overcoming sich deficiencies.

\subsection{Pragmatics}

Pragmatics is defined by different scholars in different ways. Yule (1996) defines pragmatics as the study of speakers' meaning, contextual meaning, how more gets communicated than said, and the expression of the relative distance. Stalnaker (1972) defines pragmatics as the study of linguistic acts and the context in which they are performed. For Crystal (1997, as cited in Rose \& Kasper, 2001), pragmatics is:

the study of language from the point of view of users, especially of the choices they make, the constraint they 
encounter in using the language in social interaction and the effects their use of language has on other participants in the act of communication (p.2).

The same as the diversity in definitions, pragmatics is diverse in aspects too. According to Bardovi-Harlig and Taylor (2003), pragmatics encompasses speech acts, conversational structure, conversational implicatures, conversational management, discourse organization, and sociolinguistics aspects of language use such as choice of address forms. Among these different aspects, speech acts have attracted the most attention in the literature of pragmatics and are a focus of the present study as well. Yule (1996) defines speech acts as actions performed via utterances, while for Cohen (2008) speech acts are the patterned, routinized language that natives and pragmatically competent nonnative speakers of and writers in a given speech community (with its dialect variation) use to perform functions such as thanking, complimenting, requesting, refusing, apologizing, and complaining.

\subsection{Pragmatic Instruction}

The necessity of teaching pragmatics to language learners comes from the severe consequences which pragmatic failure could have on communication (Eslami-Rasekh, 2005; Murray, 2009). A further reason which makes teaching pragmatics an obligation is the fact that pragmatic competence does not develop with grammatical competence and that is why many grammatically advanced learners continue to make pragmatic errors. According to Bardovi-Harlig (1996, as cited in Crandall \& Basturkmen, 2004, p. 38), "a learner of high grammatical proficiency will not necessarily show concomitant pragmatic competence - a real concern given that people are more forgiving; it seems, of grammatical mistakes than of pragmatic failure".

Even though some aspects of pragmatic knowledge are universal and common among all languages, many aspects of L2 pragmatics, according to Bardovi-Harlig (2001), are not acquired without the benefit of instruction, or they are learned more slowly. When confronted with such aspects of pragmatic competence, two options are available for language instructors. On one side are those who believe that exposure to language alone can lead to pragmatic knowledge; on the other side are those who believe in the role of instruction. Rose (2005) believes that this distinction addresses the issue of whether pedagogical intervention in pragmatics leads to more effective learning than no instruction, or to put another way, whether instruction is better than simple exposure.

Those who are in favor of instruction draw mainly on Schmidt's Noticing Hypothesis. According to this hypothesis, those aspects of pragmatics which are apparent to learners will be acquired better than those which are not. Many studies have been done so far to measure the efficacy of each method and the possible superiority of each upon the other (Billmyer, 1990; Bouton, 1994; Lyster, 1994; Wishnoff, 2000; Yoshimi, 2001). In most of the studies two groups were compared. In one group learners received instruction on the target pragmatic aspect while in the other group, no instruction was received at all. The results demonstrated that without any exception, the groups receiving instruction performed better than the groups which received no instruction, although sometimes, the control groups had some degrees of learning too.

A further debate which exists in the field of pragmatic instruction is among those who advocate explicit and those who prefer implicit approaches of teaching pragmatics. Many argue that the explicit versus implicit distinction is not much different from the instruction versus exposure distinction. According to Rose (2005), an important difference is that while studies in the second group compared instruction to exposure which was not manipulated to ensure that it contained the target features, studies in this group involved two (or more) treatments that ensured that learners were exposed to and used the target features. The main feature distinguishing one group from another was the provision of metapragmatic information designed to make the target features more salient. Again, many experiments were done with the purpose of comparing these two methods (Tateyama et al., 1997; Rose \& Ng, 2001; Takahashi, 2001; Martinez-Flor \& Fukuya, 2005; Alcon Soler, 2005), and except some inconsistencies, most confirmed the advantage of explicit instruction of pragmatics.

\subsection{Pragmatic Assessment}

As the focus of language teaching and learning shifted from formal aspects of language to the ability to communicate, the need of developing assessment means which measure communicative competence, part of which is pragmatic competence, became evident. Olshtain and Blum-Kulka (1985) believe that the need to measure communicative competence derives from the shift of attention in many modern language programs today toward such competence. Since language testing is an important ingredient of any educational program, the testing techniques and the various test batteries developed to serve the program should be compatible with the course objectives.

Olshtain and Blum-Kulka (1985) put the ability of using and comprehending different speech acts at the heart of 
pragmatic competence and believe that the diversity of speech act realizations stems from three types of variability which should be taken into account in developing data elicitation tools. They call these three types of variability Intracultural Variability, Intercultural Variability (Cross-cultural variability), and Individual Variability.

Considering these different types of variability, researchers have developed different tools of collecting data about pragmatic competence of language learners. According to Olshtain and Blum-Kulka (1985), the most authentic data collection of speech acts is done via ethnographic means. In this approach, the researcher attends real situations and observes speech act behavior of people and takes notes or records the whole discourse. However, despite its apparent advantages, this method imposes several difficulties on researchers specially when used in the classroom context because it requires equipping all language learners with recording devices. To escape such barriers, researchers had to utilize less authentic data collection tools. The most popular pragmatic tests developed so far are written discourse completion task (WDCT), multiple-choice discourse completion task (MDCT), oral discourse completion tasks (ODCT), discourse role-play tasks (DRPT), discourse self-assessment tasks (DSAT), and role play self-assessments (RPSA). However, Olshtain and Blum-Kulka (1985) believe that no single pragmatic test can capture the true pragmatic competence level of language learners and it is beneficial to use different methods to gain a clear picture.

\subsection{Pragmatics and ELT Materials}

Pragmatics has proved to be an inseparable part of any human language and one that needs to be conveniently incorporated into the curriculum of any language teaching context. A teaching context usually consists of a teacher and some teaching materials, such as books, video/audio stuffs, pictures, etc. (An exception is the distance learning environments in which there is usually no teacher in its conventional form). Such materials cannot be ignored because no single teacher is capable of knowing everything about a subject matter or transferring it appropriately to the learners.

English language teaching is no exception, and this is evident from the numerous ELT materials which come to the market every year. For years, the main focus of such materials has been the formal aspects of language such as grammar, vocabulary, pronunciation, etc., with little emphasis on pragmatics or the patterns of English use. However, the current trend toward incorporating pragmatics into the classroom curriculum necessitates the development of materials suitable for this purpose, a necessity that many scholars have confirmed too (Crandall \& Basturkmen, 2004)

Another matter that highlights the importance of teaching resources in developing pragmatic competence of language learners is the proven superiority of explicit teaching discussed above. With the increasing evidence in favor of explicit instruction of pragmatics, one may ask about the adequacy of resources which are currently used to teach pragmatics. In most of EFL and ESL contexts, textbooks are the main source of teaching. Their role is more prominent in EFL contexts where for most of students, the only source of input is the textbooks (Kim \& Hall, 2002).

Many researchers have questioned the adequacy of textbooks (Bardovi-Harlig, 2001; Crandall \& Basturkmen, 2004; Vellenga, 2004). Bardovi-Harlig (2001) argues that "it is important to recognize, that, in general, textbooks cannot be counted on as a reliable source of pragmatic input for classroom language learners" (p. 25). In general, most of the researchers agree that textbooks are not sufficient sources for teaching pragmatics in the classroom and supplementary materials or knowledgeable teachers are needed to make up for their shortcomings.

\subsection{Learners' Pragmatic Awareness}

In contrast to native speakers who are intuitively aware of the pragmatic rules of their language, adult second language learners do not benefit from such awareness. In addition, it has been found that pragmatic awareness does not develop hand in hand with grammatical awareness, so we need specific activities for raising pragmatic awareness of language learners (Bardovi-Harlig \& Dörneyei, 1997). Different researchers have acknowledged the necessity of raising pragmatic awareness of both language instructors and language learners.

In Schauer's (2006) study titled "Pragmatic Awareness in ESL and EFL Contexts: Contrast and Development", two research questions were addressed: a) Do learners in English as a foreign language (EFL) and English as a second language (ESL) contexts display differences in their recognition and rating of pragmatic and grammatical competence? b) Do ESL learners increase their pragmatic awareness during an extended stay in the target environment? As many as 53 participants, 16 German students studying at a British university, 17 German students studying in a higher education institution in Germany, and 20 native British English speaking controls took part in the study. Data was gathered using Bardovi-Harlig and Dönyei's video and questionnaire instrument. 
Findings revealed that German EFL participants have the least awareness of pragmatic errors and the ESL participant increased their level of pragmatic comparison during their stay in the Britain.

In Bardovi-Harlig and Griffin (2005), the researchers used a pragmatic awareness activity before giving the ESL learners formal instruction in pragmatics. Their purpose was to recognize the kind of infelicities which learners could recognize and their ability to correct such errors. Five intact classes consisting of 43 students from 18 language backgrounds took part in the study. Participants were shown some video-taped scenarios and they worked in pairs to identify the pragmatic errors and then performed short role plays to repair those errors. The results revealed that in general, learners are able to recognize a pragmatic infelicity such as a missing speech act, but the content of their repairs is different from that of native speakers. Such inappropriacy of content can be a good indicator of what to teach learners in the field of pragmatics.

Eslami-Rasekh's (2005) article titled "Raising the Pragmatic awareness of Language Learners," aimed to investigate the possibility of teaching pragmatics to Iranian language learners and raising their pragmatic awareness. For this purpose, the researcher used different kinds of activities.

In one activity, Iranian learners were given DCTs which they were supposed to complete in Persian and then literary translate into English. Such translations were then compared with answers given by American native speakers to the same DCTs. The goal of such activity was to motivate students and show them how culture and language are interrelated and how some specific speech acts in their mother tongue cannot easily be translated into English.

In another activity type, learners were presented with examples of cross-cultural miscommunication and problematic interactions. Such examples were provided both by the instructor and by students based on their experiences with English native speakers. Such activities, according to the researcher, can be a rich source of pragmatic data and give learners an opportunity to discuss the existing infelicities and the possible alternatives to correct them.

As a final tactic to raise learners' pragmatic awareness, students became researchers themselves and observed native speakers real behavior. Such observations were either open or structured. In open observations students focused on what they perceived to be important, while in structured observation they were given an observation sheet that determined the categories which the students should be observing. Such categories included the gender, age, and social status of the interlocutors, their distance and level of dominance, the place and tile of interaction, the type of offence committed, and the intensity of the offence. Collecting data using the last technique is not very easy and practical in EFL contexts in comparison to ESL contexts because there is lack of access to native speakers. The researcher, however, suggests using audiocassettes and videocassettes and analyzing them to remedy this problem in EFL contexts. There are, however, other researchers who do not view such materials as authentic sources of pragmatic data because of their rehearsed nature (Cohen, 2007).

Despite the proved role of pragmatic competence for successful communication, we still rarely see a deserving role for pragmatics in EFL classrooms which are the first and the most important place for teaching pragmatics to students. Although many studies have been conducted so far on the topic of pragmatics, we still rarely see the application of their findings in the Iranian EFL teaching context. As the above literature review demonstrates, there are a number of different factors which contribute to pragmatic awareness of English language learners. On the more manifest layers, we have teachers and students and on the underneath layers there are other stake holders such as teacher preparation centers, materials developers, publishers, curriculum designers, etc. Therefore, we cannot say with certainty which one/ones should be blamed for this lack of application. To shed light on the status of pragmatics among Iranian EFL learners, the present study attempts to address the following research questions:

1) What is the status of pragmatic awareness among Iranian EFL learners in terms of the amount of pragmatic knowledge they have, and the amount of pragmatic knowledge they receive from teachers, classmates, course books, and exams?

2) Is there any significant difference between Iranian male and female EFL learners in terms of the status of pragmatic awareness?

The second research question gave rise to the following null hypothesis, whereas no null hypothesis was formulkated for the first research due to the nature of the question.

Null hypothesis: There is no significant difference between Iranian male and female EFL learners in terms of the status of pragmatic awareness. 


\section{Method}

\subsection{Participants}

Participants of this study were intermediate to advanced EFL learners from a variety of cities and language institutes due to the nation-wide nature of the study. There were two groups of participants in this study: the pilot group and the main group. The pilot group consisted of 100 language learners. The language learners were 55 females and 45 males, all belonging to intermediate to advanced levels of English proficiency. The main group of participants included 477 language learners that consisted of 216 males and 261 females. The only criterion to select the language learners was their being from intermediate to advanced level of language proficiency. Participants were selected from 14 language teaching institutes in Tehran, Isfahan, Shiraz, and Sharekord (See appendix B for a list of the institutes).

\subsection{Data Collection Tool and Procedure}

Data was collected via a multiple-choice format questionnaire developed by Dr. Zia Tajeddin (See appendix A). The questionnaire began with a number of general questions about learners' university degree/school level, major, age, gender, years of experience in language learning, the institute in which they learnt English, the books they studied, and whether or not they had the experience of living in an English speaking country. Following that, there was a short explanation regarding the nature of pragmatics as intended in this study. The questionnaire had four components named Language Learner, Language Teacher, Classmates and Institute, Course books and Exams, amounting to 24 items.

The Language Learner component examined learners' pragmatic knowledge and awareness. In the Language Teacher component, the researchers sought to determine the amount of care given to pragmatics by teachers, either in teaching or in assessment activities, from the point of view of learners. The Classmates and Institute component attempted to reveal the extent of pragmatic feedback learners received from and gave to their classmates. The final component, Course books and Exams, aimed to examine course books' and exams' pragmatic quality from learners' perspective.

Each item in the questionnaire was followed by five options, for the purpose of a Likert Scale analysis, such as: 1) Strongly Disagree, 2) Disagree, 3) Neither Agree nor Disagree, 4) Agree, 5) Strongly Agree. The options were organized in a way that number (1) was representative of the lowest value and number (5) was representative of the highest value for the intended question. In interpreting the results, a mean score of 1 to 2 was considered low, 2 to 3.5 was average, and 3.5 to 5 was high

Before distributing the questionnaires among the main population of the study, a pilot study was carried out to verify the reliability of the questions. The pilot study was conducted with 100 language learners from seven language institutes in Isfahan. The participants were told that the questionnaire was for research purpose and were asked to answer the questions at home. After collecting the questionnaires, the data was subjected to analysis to determine the reliability of the questionnaires, which amounted to 0.89 . This high reliability index proved the trustworthiness of the questionnaire for further investigations. After calculating the reliability, the questionnaires were given to the main group of the study which consisted of 477 language learners. Likewise, the participants were notified about the purpose of the questionnaires and were told to complete it at home.

\section{Results}

\subsection{Research Question One}

What is the status of pragmatic awareness and instruction among Iranian EFL learners in terms of the amount of pragmatic knowledge they have, and the amount of pragmatic knowledge they receive from teachers, classmates, course books, and exams?

As mentioned, the questionnaire consisted of four components, each concentrating on the status of pragmatic awareness among Iranian EFL learners from one dimension. The Language Learner component had nine items (items 1 to 9) which sought to inspect language learners' own knowledge of and attitude toward the concept of pragmatics. In the second component, Language Teacher, six items (items 10 to 15) were utilized to explore language learners' attitude about the status of pragmatic awareness among their teachers and the amount of pragmatic knowledge they received from teachers. The third component, named Classmates and Institute, included four items (items 16 to 19) which investigated the value given to pragmatics by learners' classmates. And the last component, Course books and Exams, had five items (items 20 to 24) that language learners rated based on the status that they felt pragmatics had in course books and exams. The first step was estimating minimum, maximum, mean, and standard deviation of each component of the questionnaire and the total questionnaire. 
Table 1. Minimum, maximum, mean, and std. deviation of the questionnaire

\begin{tabular}{llllll}
\hline & $\mathrm{N}$ & Minimum & Maximm & Mean & Std. Deviation \\
\hline Component 1 & 477 & 1.44 & 7.22 & 3.8544 & .58715 \\
Component 2 & 477 & 1.00 & 12.17 & 3.5828 & .86876 \\
Component 3 & 477 & 1.00 & 5.00 & 2.8077 & .86014 \\
Component 4 & 477 & 1.00 & 5.00 & 3.0029 & .74546 \\
Total & 477 & 1.42 & 5.50 & 3.4347 & .52749 \\
\hline
\end{tabular}

As evident from Table 1, the means achieved for components 1 and 2 of the questionnaire, i.e. Language Learner and Language Teacher, were 3.85 and 3.58, respectively. It means that the participants had a high degree of pragmatic awareness as language learners, and they believed that their teachers, too, had a high level of pragmatic awareness. In components 3 and 4 of the questionnaire, however, the participants achieved average means; 2.80 for component 3 and 3.00 for component 4 . It can be concluded that language learners perceived an average status for pragmatics among classmates and institutes, as well as, in course book and exams. Taking into account the four components of pragmatic awareness together, the obtained mean score was 3.43, which demonstrated an average status for pragmatic awareness among Iranian EFL learners. However, it cannot be ignored that the value was close to 3.5. Below, the mean of each individual item in the questionnaire is presented.

Table 2. Minimum, maximum, mean, and std. deviation of items 1 to 24

\begin{tabular}{llllll}
\hline & $\mathrm{N}$ & Minimm & Maximm & Mean & Std. Deviation \\
\hline Item 1 & 477 & 1.00 & 5.00 & 3.57 & .95 \\
Item 2 & 477 & 1.00 & 5.00 & 4.14 & .82 \\
Item 3 & 477 & 1.00 & 5.00 & 3.25 & .83 \\
Item 4 & 477 & 1.00 & 5.00 & 4.14 & .84 \\
Item 5 & 477 & 1.00 & 5.00 & 4.19 & .88 \\
Item 6 & 477 & 1.00 & 5.00 & 4.09 & .88 \\
Item 7 & 477 & 1.00 & 5.00 & 3.75 & .87 \\
Item 8 & 477 & 1.00 & 5.00 & 3.94 & .75 \\
Item 9 & 477 & 1.00 & 5.00 & 3.53 & .91 \\
Item 10 & 477 & 1.00 & 5.00 & 3.54 & .98 \\
Item 11 & 477 & 1.00 & 5.00 & 3.40 & .96 \\
Item 12 & 477 & 1.00 & 5.00 & 3.80 & 1.04 \\
Item 13 & 477 & 1.00 & 5.00 & 3.93 & .97 \\
Item 14 & 477 & 1.00 & 5.00 & 3.62 & .99 \\
Item 15 & 477 & 1.00 & 5.00 & 3.08 & 1.04 \\
Item 16 & 477 & 1.00 & 5.00 & 2.78 & 1.04 \\
Item 17 & 477 & 1.00 & 5.00 & 2.59 & .96 \\
Item 18 & 477 & 1.00 & 5.00 & 2.93 & 1.10 \\
Item 19 & 477 & 1.00 & 5.00 & 2.91 & 1.07 \\
Item 20 & 477 & 1.00 & 5.00 & 3.16 & .93 \\
Item 21 & 477 & 1.00 & 5.00 & 2.94 & .96 \\
Item 22 & 477 & 1.00 & 5.00 & 2.89 & 1.03 \\
Item 23 & 477 & 1.00 & 5.00 & 3.02 & .97 \\
Item 24 & 477 & 1.00 & 5.00 & 2.98 & 1.04 \\
\hline
\end{tabular}


In component 1 of the questionnaire (items 1 to 9), the highest mean (4.19), belonged to item 5, "Pragmatics is an important aspect of language learning", and the lowest mean (3.25) belonged to item 3, "I evaluate my own pragmatic competence as very good".

In the second component of the questionnaire (item 10 to 15), item 13, "our language teacher corrects our pragmatic errors", had the highest mean (3.93) and item 15, "I ask my language teachers questions about pragmatic issues", had the lowest mean (3.08).

In component 3 (items 16 to 19), the lowest mean (2.59) belonged to item 17, "My classmates comment on my pragmatic ability and appropriateness", and the highest mean (2.93) belonged to item 18, "My classmates and I discuss the need to pay attention to pragmatic features in the course book".

In the final component of the questionnaire (items 20 to 24), item 22, "There are supplementary materials in this institute to teach pragmatic competence to us", had the lowest mean (2.89); and item 20, "Activities in the course book include features related to pragmatic competence", had the highest one (3.16).

\subsection{Research Question Two}

Is there any significant difference between Iranian male and female EFL learners in terms of the status of pragmatic awareness and instruction?

To answer this question, the data was first subject to descriptive statistics and the means of male and female language learners were calculated.

Table 3. Mean and std. deviation of Iranian male and female language learners

\begin{tabular}{llllll}
\hline & Gender & $\mathrm{N}$ & Mean & Std. Deviation & Std. Error Mean \\
\hline Component 1 & male & 216 & 3.7145 & .64277 & .04373 \\
& female & 261 & 3.9702 & .50970 & .03155 \\
Component 2 & male & 216 & 3.4799 & 1.01264 & .06890 \\
& female & 261 & 3.6679 & .71954 & .04454 \\
Component 3 & male & 216 & 2.7384 & .86528 & .05887 \\
& female & 261 & 2.8649 & .85328 & .05282 \\
Component 4 & male & 216 & 2.9491 & .74696 & .05082 \\
& female & 261 & 3.0475 & .74268 & .04597 \\
Total & male & 216 & 3.3337 & .59243 & .04031 \\
& female & 261 & 3.5182 & .45135 & .02794 \\
\hline
\end{tabular}

In component 1 of the questionnaire, male learners achieved a mean score of 3.71 and females had a mean of 3.97 , both indicating high level of pragmatic awareness. In the second component, male and female learners obtained mean scores of 3.47 and 3.66, respectively. Mean of males in this component was representative of average pragmatic awareness assigned to teachers, while that of females showed high pragmatic awareness. In component 3, "Classmates and Institute", males got a mean of 2.73 and females 2.86. It illustrated that both gender categories associated an average status to pragmatics among the classmates and the institutes. In the final component, males accomplished a mean score of 2.94 and females attained a mean of 3.04. Again both values illustrated average status of pragmatics in course books and exams. When considering all four components together, female got a mean of 3.51, which indicated high pragmatic awareness among female learners, while males obtained a mean of 3.33 that signified average pragmatic awareness among male language learners.

Then, several t-tests were conducted to see whether or not the mean differences of males and females were significant. In other words, the t-tests were utilized to find out if gender had a significant effect on the status of pragmatic awareness and instruction among Iranian EFL learners. 
Table 4. T-test between Iranian male and female language learners' performance

\begin{tabular}{|c|c|c|c|c|c|c|c|c|}
\hline & & \multicolumn{7}{|c|}{$\begin{array}{l}\text { Levene's Test for } \\
\text { Equality of Variances }\end{array}$} \\
\hline & & $\mathrm{F}$ & Sig & $\mathrm{t}$ & $\mathrm{df}$ & $\begin{array}{l}\text { Sig. } \\
\text { (2-tailed) }\end{array}$ & $\begin{array}{l}\text { Mean } \\
\text { Differene }\end{array}$ & $\begin{array}{l}\text { Std. Error } \\
\text { Difference }\end{array}$ \\
\hline \multirow{2}{*}{ Component 1} & EVA & 18.995 & .000 & -4.749 & 475 & .000 & -2.17864 & .45872 \\
\hline & EVNA & & & -4.614 & 384.082 & .000 & -2.17864 & .47221 \\
\hline \multirow{2}{*}{ Component 2} & EVA & 5.509 & .019 & -3.212 & 475 & .001 & -1.35951 & .42330 \\
\hline & EVNA & & & -3.172 & 431.238 & .002 & -1.35951 & .42857 \\
\hline \multirow{2}{*}{ Component 3} & EVN & .617 & .433 & -1.602 & 475 & .110 & -.50607 & .31596 \\
\hline & EVAN & & & -1.600 & 456.056 & .110 & -.50607 & .31637 \\
\hline \multirow{2}{*}{ Component 4} & EVN & .617 & .433 & -1.602 & 475 & .110 & -.50607 & .31596 \\
\hline & EVAN & & & -1.600 & 456.056 & .110 & -.50607 & .31637 \\
\hline \multirow{2}{*}{ Total } & EVN & 14.504 & .000 & -4.075 & 475 & .000 & -4.53640 & 1.11311 \\
\hline & EVAN & & & -3.976 & 396.567 & .000 & -4.53640 & 1.14106 \\
\hline
\end{tabular}

Note. $\mathrm{EVN}=$ Equal variances assumed; $\mathrm{EVAN}=$ Equal variances not assumed; $\mathrm{df}=$ Degree of freedom.

The first t-test concentrated on the first component of the questionnaire, i.e., Language Learner. The observed value of $t$ was 4.74, that was higher than the critical value of $t(1.960)$ at the .05 level of significance and 475 degree of freedom: $\mathrm{t}(475)=4.61, \mathrm{p}<.05$. The results confirmed that gender had a significant effect on language learners' performance on the first component of the questionnaire. Therefore, the null hypothesis was rejected. By looking at Table 4.3, it can be concluded that female learners (3.97) significantly outperformed male learners (3.71) on this component of the questionnaire.

The next $t$-test was related to the second component of the questionnaire, Language Teacher. The observed value of $t$ was 3.212, which was larger than the critical value of $t(1.960)$ at .05 level of significance: $t(475)=3.17, p<$ 0.05. It revealed that male and female language learners performed differently on the Language Teacher component of the questionnaire; leading to the rejection of the null hypothesis. Here again, female learners revealed to have a statistically significant higher pragmatic awareness (3.66) than male learners (3.47).

The third t-test addressed the Classmates and Institute component of the questionnaire. This time we encountered results which were different from the previous t-test results since the observed value of $t$ (1.60) was lower than the critical value of $\mathrm{t}(1.960)$; hence, result was insignificant. In other words, in this component of the questionnaire, male and female participants did not perform differently: $\mathrm{t}(475)=1.602, \mathrm{p}<.05$; and the null hypothesis was not rejected.

The forth t-test dealt with the fourth component of the questionnaire. Again, the observed value of $t(1.60)$ turned to be lower than the critical value of $\mathrm{t}(1.960)$; leading to the confirmation of the null hypothesis, and the conclusion that gender had no effect on language learners' performance on the Course Book and Exam component of the questionnaire: $\mathrm{t}(475)=1.437, \mathrm{p}<.05$.

Finally, a t-test for the total questionnaire was conducted to find out whether or not the mean difference of males and females in answering the total questionnaire was statistically significant. The value of observed $t$ was 4.07, which was higher that the value of critical $t(1.960)$ at the .05 level of significance: $t(475)=4.07, p<.05$. It means that gender had an effect on language learners' performance on the whole questionnaire. Consulting table 4.3, it is evident that female learners had a higher mean (3.51) on the total questionnaire than male learners (3.33), directing to the conclusion that females had a significantly higher degree of pragmatic awareness, when taking into account the four components of pragmatic awareness together.

\section{Discussion}

Data analysis revealed that Iranian EFL learners had a high level of pragmatic awareness. It means that they were aware of the significant role which pragmatics plays in appropriate communication. However, this is not the whole story. Unfortunately, such awareness did not mean that they had enough knowledge and competence in pragmatics, or that they used it in real communication. As students admitted themselves, they did not have 
sufficient pragmatic competence.

When learners were asked about their teachers' level of pragmatic awareness and the amount of pragmatic knowledge transferred to them by teachers, they assigned teachers a high degree of pragmatic knowledge. But, when asked about the methods used in classroom to teach pragmatics, it was revealed that teachers seldom had explicit discussion of pragmatic concepts, and dealing with pragmatics was mostly limited to error correction or whatever which existed in the course books.

Another focus of the study was investigating the status of pragmatic awareness among learners' classmates. Learners assigned an average status to pragmatics among their classmates. Based on the results, it was demonstrated that although pragmatic-related talks were sometimes exchanged between learners and their classmates, classmates did not consider pragmatics an important element of learners' language competence.

The last component of pragmatic awareness in the questionnaire was related to course books and exams which were used to teach and assess the language. Here again the overall status of pragmatics was average. Learners confirmed that there were parts related to pragmatics in the course books and the exams, but they also believed that these parts were not enough by themselves to boost pragmatic competence in language learners. When asked whether or not supplementary materials were used to compensate for this lack, the majority said that such materials were barely used.

In general, pragmatics does not have a promising status among Iranian EFL learners. Many factors contribute to this unsteady place. On the one hand are teachers with their inappropriate methods of teaching pragmatics, or insufficient time and attention devoted to it. On the other hand are the institutes' directors and syllabus designers, and the course books and exam compilers who do not incorporate pragmatics adequately in their materials.

Besides exploring the status of pragmatic awareness, this study had a secondary purpose which was investigating effect of gender type on learners' pragmatic awareness. Results showed that except in components 3 and 4, female learners had a statistically better performance than males, and in components 3 and 4 no significant difference was observed between them. When comparing mean scores of males and females on the total questionnaire, again female learners outperformed their male counterparts. It means that females had a higher level of pragmatic awareness than males. However, further studies are needed to confirm the results.

\section{Acknowledgments}

I would like to express my appreciations to my supervisor Dr. Zia Tajeddin from University of Allameh Tabatabai, Tehran, for guiding me through the different steps of this research and for developing the questionnaire used in this research.

\section{References}

Alcon Soler, E. (2005). Does instruction work for learning pragmatics in the foreign language context? System, $33(3), 417-435$

Bachman, L. F. (1990). Fundamental considerations in language testing. Oxford: Oxford University Press.

Bachman, L. F., \& Palmer, A. (1996). Language testing practice. Oxford: Oxford University Press.

Bardovi-Harlig, K. (2001). Evaluating the empirical evidence: Grounds for instruction in pragmatics. In K. R. Rose, \& G. Kasper (Eds.), Pragmatics in language teaching (pp. 13-32). Cambridge: Cambridge University Press.

Bardovi-Harlig, K., \& Dörnyei, Z. (1998). Do language learners recognize pragmatic violations? pragmatic versus grammatical awareness in instructed 12 learning. TESOL Quarterly, 32(2), 233-262.

Bardovi-Harlig, K., \& Griffin, R. (2005). L2 pragmatic awareness: Evidence from the ESL classroom. System, $33,401-415$.

Bardovi-Harlig, K., \& Mahan-Taylor, R. (2003). Introduction to teaching pragmatics. English Teaching Forum, $41(3)$.

Billmyer, K. (1990). I really like your life style: ESL learners learning how to compliment. Penn Working Papers in Educational Linguistics, 6(2), 31-48.

Bouton, L. (1994). Conversational implicature in the second language: Learned slowly when not deliberately taught. Journal of Pragmatics, 22, 157-167.

Canale, M. (1983). From communicative competence to communicative language pedagogy. In J. C. Richards, \& R. W. Schmidt (Eds.), Language and communication (pp. 2-27). London: Longman. 
Canale, M., \& Swain, M. (1980). Theoretical bases of communicative approaches to second language teaching and testing. Applied Linguistics, 1, 1-47.

Cohen, A. D. (2007). The teaching of pragmatics in the EFL classroom. ILI Language Teaching Journal, 3(2), $1-27$.

Cohen, A. D. (2008). Teaching and assessing L2 pragmatics: What can we expect from learners? Language Teaching, 41(2), 213-235.

Crandball, E., \& Basturkmen, H. (2004). Evaluating pragmatics-focused materials. ELT Journal, 58(1), 38-49.

Eslami-Rasekh, Z. (2005). Raising the pragmatic awareness of language learners. ELT Journal, 59(3).

Kim, D., \& Hall, J. K. (2002). The role of an interactive book reading program in the development of second language pragmatic competence. Modern Language Journal, 86, 332-348.

Lyster, R. (1994). The effects of functional analytic teaching on aspects of french immersion students' sciolinguistic competence. Applied Linguistics, 15, 263-287.

Martinez-Flor, A., \& Fukuya, Y. J. (2005). The effects of instruction on learners' production of appropriate and accurate suggestions. System, 33, 463-480.

Murray, N. (2009). Pragmatics, awareness raising, and the cooperative principle. ELT Journal, 64(3), 293-301.

Olshtain, E., \& Blum-Kulka, S. (1985). Cross-cultural pragmatics and the testing of communicative competence. Language Testing, 2(1), 16-30.

Rose, K. R. (2005). On the effects of instruction in second language pragmatics. System, 33, 358-399.

Rose, K. R., \& Kasper, G. (Eds.). (2001). Pragmatics in language teaching. New York: Cambridge University Press.

Rose, K., \& Ng, K. F. C. (2001). Inductive and deductive teaching of compliments and compliment responses. In K. R. Rose, \& G. Kasper (Eds.), Pragmatics in language teaching (pp. 145-170). New York: Cambridge University Press.

Schauer, G. A. (2006). Pragmatic awareness in ESL and EFL contexts: Contrast and development. Language Learning, 56(2), 269-318.

Schmidt, R. (1990). The role of consciousness in second language learning. Applied Linguistics, 11(2), 129-158.

Schmidt, R. (1993). Consciousness, learning, and interlanguage pragmatics. In G. Kasper, \& S. Blum-Kulka (Eds.), Interlanguage pragmatics (pp. 21-42). Oxford: Oxford University Press.

Stalnaker, R. (1972). Pragmatics. In D. Davidson, \& G. Harman (Eds.), Semantics of natural language (pp. 380-397). New York: Springer.

Takahashi, S. (2001). The role of input enhancement in developing pragmatic competence. In K. R. Rose, \& G. Kasper (Eds.), Pragmatics in language teaching (pp. 171-199). Cambridge: Cambridge University Press.

Tateyama, Y., Kasper, G., Mui, L., Tay, H., \& Thananart, O. (1997). Explicit and implicit teaching of pragmatic routines. In L. Bouton (Ed.), Pragmatics and language learning (vol. 8, pp. 163-178). Urbana IL: University of Illinois at Urbana-Champaign.

Vellenga, H. (2004). Learning pragmatics from ESL and EFL textbooks: How Likely? TESL-EJ Journal, 8(2).

Wishnoff, J. (2000). Hedging your bets: L2 learners' acquisition of pragmatic devices in academic writing and computer-mediated discourse. Second Language Studies: Working Papers of Second Language Studies, University of Hawai'i.

Yoshimi, D. R. (2001). Explicit instruction and JFL learner's use of interactional discourse markers. In K. R. Rose, \& G. Kasper (Eds.), Pragmatics in language teaching (pp. 223-244). Cambridge: Cambridge University Press.

Yule, G. (1996). Pragmatics. Oxford: Oxford University Press.

\section{Appendix A}

\section{Language Learner Questionnaire}

Understanding Language Learners' Pragmatic Awareness

Participant Background 
University degree/grade in high school:

Major: Age:

Gender: Male Female

Years of experience in learning English: $\quad 1-2 \quad 3-5 \quad 6-10 \quad 11+$

Residence in an English-speaking country: No Yes (for......years)

Name of the institute you learn English at:

Your level at the institute:

Name of the course book which you study at this institute:

Directions: The items below aims to investigate your views about your ability to appropriately use language functions. This ability is called pragmatic competence and helps you use language functions such as greeting, request, refusal, apology, complaint, thanking, and compliment in different formal and informal situations. Please read each item about the importance of this ability in your English class, course book and exams, and then check the most appropriate response.

\section{A. Language Learner}

1. I am familiar with the concept of pragmatics in language learning.

\section{Strongly Disagree $\quad 2$. Disagree $\quad 3$. Neither Agree nor Disagree \\ 4. Agree 5. Strongly Agree}

2. Pragmatic competence is important for me as a language learner.
1. Strongly Disagree
2. Disagree
3. Neither Agree nor Disagree
4. Agree 5. Strongly Agree

3. I evaluate my own pragmatic competence as very good.

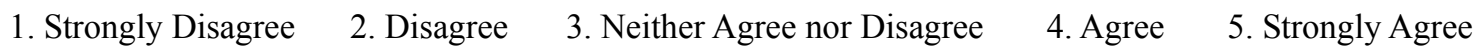

4. I try to improve my pragmatic competence.
1. Strongly Disagree
2. Disagree
3. Neither Agree nor Disagree
4. Agree
5. Strongly Agree

5. Pragmatics is an important aspect of language learning.
1. Strongly Disagree
2. Disagree
3. Neither Agree nor Disagree
4. Agree 5. Strongly Agree

6. The instruction of pragmatic competence should be part of an effective language teaching program.
1. Strongly Disagree
2. Disagree
3. Neither Agree nor Disagree
4. Agree
5. Strongly Agree

7. The measurement of language learners' pragmatic competence should be part of an effective language testing program.
1. Strongly Disagree
2. Disagree
3. Neither Agree nor Disagree
4. Agree
5. Strongly Agree

8. Language learners' pragmatic competence should be considered to be important for successful language learning.
1. Strongly Disagree
2. Disagree
3. Neither Agree nor Disagree
4. Agree
5. Strongly Agree

9. Language learners' pragmatic competence should be considered as a factor in their exams.
1. Strongly Disagree
2. Disagree
3. Neither Agree nor Disagree
4. Agree
5. Strongly Agree

\section{B. Language Teacher}

10. Our language teacher makes us aware of the significance of pragmatics competence in language learning.
1. Never
2. Seldom
3. Sometimes
4. Usually
5. Always

11. Our language teacher assesses our pragmatic competence.
1. Never
2. Seldom
3. Sometimes
4. Usually
5. Always

12. Our language teacher pays attention to our pragmatic errors (e.g. when we greet inappropriately).
1. Never
2. Seldom
3. Sometimes
4. Usually
5. Always

13. Our language teacher corrects our pragmatic errors.
1. Never
2. Seldom
3. Sometimes
4. Usually
5. Always

14. Our language teacher cares about pragmatic competence in evaluating our classroom activities. 

1. Never
2. Seldom
3. Sometimes
4. Usually
5. Always

15. I ask my language teacher questions about pragmatic issues (e.g. how to make a request appropriately).
1. Never
2. Seldom
3. Sometimes
4. Usually
5. Always
C. Classmates and Institute
16. My classmates and I discuss the issues related to pragmatic competence.
1. Never
2. Seldom
3. Sometimes
4. Usually
5. Always

17. My classmates comment on my pragmatic ability and appropriateness.
1. Never
2. Seldom
3. Sometimes
4. Usually
5. Always

18. My classmates and I discuss the need to pay attention to pragmatics features in the course book.
1. Never
2. Seldom
3. Sometimes
4. Usually
5. Always

19. My classmates consider my pragmatic competence as feature of my success in language learning.
1. Never
2. Seldom
3. Sometimes
4. Usually
5. Always
D. Course Book and Exams

20. Activities in the course book include features related to pragmatic competence.
1. Not at All True
2. Slightly True
3. Halfway True
4. Mostly True
5. Totally True

21. Activities in the course book are sufficient for improving our pragmatic competence.
1. Not at All True
2. Slightly True
3. Halfway True
4. Mostly True
5. Totally True

22. There are supplementary materials at this institute to teach pragmatic competence to us.
1. Not at All True
2. Slightly True
3. Halfway True
4. Mostly True
5. Totally True

23. There are questions in the institute's exams which assess our pragmatic competence.
1. Not at All True
2. Slightly True
3. Halfway True
4. Mostly True
5. Totally True

24. The institute's exams encourage us to focus on pragmatic features in our course book.
1. Not at All True
2. Slightly True
3. Halfway True
4. Mostly True
5. Totally True

\section{Appendix B}

\section{List of Participating Language Institutes}

\section{- Tehran}

Kish, Vanak Sq. Branch

Kish, Enghelab Sq. Branch

Kanoon Zaban (ILI), Jam St. Branch

Kanoon Zaban (ILI), Vesal St. Branch

Kanoon Zaban (ILI)

Mojtame Fanni (TIT), Saadat Abad Branch

Mojtame Fanni (TIT), Kashani St. Branch

Mojtame Fanni (TIT)

\section{- Isfahan}

Guyesh

Sadr

Kian e Farda

Kanoon Zaban (ILI), Nikbakht St. Branch

Kanoon Zaban (ILI), Darvaz e Shiraz Branch

Payam Persa

Parto e Danesh 
Farnam

- Shiraz

Bahar

- Shahr e Kurd

Kanoon Zaban

Jahad Daneshgahi

Omid

\section{Copyrights}

Copyright for this article is retained by the author(s), with first publication rights granted to the journal.

This is an open-access article distributed under the terms and conditions of the Creative Commons Attribution license (http://creativecommons.org/licenses/by/3.0/). 